\title{
SOVETISEERIMINE KUI EESTI RAHVUSLIKU FOLKLORISTIKA KONSERVANT
}

\author{
LIINA SAARLO
}

$O^{t}$ talinismiaegset sovetiseerimisprotsessi eesti rahvusteadustes ja sealhulgas folkloristikas tundub olevat asjakohane käsitleda suure murrangu või katkestusena (vrd Kõresaar 2005: 69-110). Nõukogude liiduvabariikide unifitseerival mudelil põhinevad struktuursed ümberkorraldused muutsid folkloristikas nii institutsionaalseid ja isikutevahelisi suhteid kui ka distsipliini asendit humanitaarteaduste kaardil. Lisaks toimus vaimu koloniseerimine, ideoloogiliselt määratletud teadusmeetodi pealesundimine, mis leidis aset impeeriumi keskustes „kogenud” nõukogude folkloristide käe all. Pidevas vajaduses vastanduda eelnenud ühiskondlikule korrale deklareeriti ka varasemate teadussaavutuste tendentslikkust ja suisa kahjulikkust, katkestades nii vähemalt diskursiivselt juba eelnenud sajandil alanud Eesti rahvusteaduste arengu. Stalinismi ajal nõukogude folkloristika moderniseerus, rahvaluule mõiste asendati rahvaloomingu mõistega ning fookusesse tõsteti kaasaegne nõukogude folkloor.

Säärases olukorras olnuks eelduspärane, et ka eesti folkloristid oleksid moderniseerunud ja muutnud lisaks diskursusele uurimisparadigmat. Ometi muutus eesti folkloristika 1950. aastate lõpuks isegi konservatiivsemaks ja rahvuslikumaks kui enne sõda. Seetõttu peab silmas pidama lähenemist, mis tõlgendab toonast rahvusteaduste ja rahvakultuuriga tegelemist kui teatavat vastupanu sovetiseerimisele (nt Aarelaid 1998: 116 jj).

Järgnevalt lahkangi valikuid, mida eesti folkloristid tegid, kohanedes nõukoguliku uurimisparadigmaga, ja seda, milliseid lahendusi nad kasutasid rahvusteadustega edasi tegelemiseks. Samuti püüan avada, kuidas folkloristika sovetiseerimisprotsessil oli eesti folkloristika arengule ootamatult konserveeriv mõju.

\section{Uued tuuled, uus keel}

Eesti sovetiseerimise periood 1940.-1950. aastatel on üpriski läbikirjutatud teema nii ajaloolaste kui ka kultuuriuurijate perspektiivist (nt Tannberg 2007; Zubkova 2009; Olesk 2003; Lippus 2008). Kuna viimase aastakümne jooksul on mitmes kontekstis kirjutatud ka stalinismiaegse eesti folkloristika institutsionaalsetest ja ideoloogilistest reformidest (nt Goršič 2017; Kulasalu 2017; Oras 2009; Saarlo 2017a, 2017b), pean siinkohal vajalikuks piirduda tähele-

* Artikli kirjutamist inspireerisid Eesti-uuringute Tippkeskuse ajalooliste väljendusja kultuuripraktikate uuringute töörühma seminaril „Humanitaarteaduste roll rahvuse (de)konstrueerimise protsessis” kõlanud Anti Selarti mõte nõukogude ajast kui „eesti-aegse” ajaloomõtte konserveerijast ning Indrek Jäätsi ettekanne nõukogudeaegsest etnograafiast. 
panu juhtimisega asjaoludele, mis suunasid toonaseid teadlasi oma valikuid tegema.

Esiteks, Nõukogude Liidu sõjajärgset elu määrasid parteijuhtide kõikuvad eelistused ning ootamatud kursimuutused, mis jõudsid lainetustena otsesemalt või kaudsemalt liiduvabariikide ja sealhulgas Eesti folkloristideni. Nõukogude impeerium kehtestas oma võimu lisaks repressioonidele (vangistamised, küüditamised jms) ka pidevalt muutuvate nõuete ja uueneva vaenlasekujuga, tekitades annekteeritud territooriumidel ebakindla ja usaldamatu õhkkonna. Eesti (nagu ka kogu Nõukogude Liidu) teadlastel oli oht sattuda kriitika ja rünnakute objektiks varem avaldatud teaduslike seisukohtade pärast - olgu siis eelmise riigikorra aegsete või ka sovetiseerimisprotsessi käigus ebasoosingusse sattunute tõttu. Üleüldise ebastabiilsuse ja öördamistega kindlustati, et värskelt okupeeritud vabariikide teadlased valisid ellujäämiseks mitte vastupanu, vaid kohastumise ja kohandumise tee.

Teiseks peab silmas pidama, et stalinistlik periood ei olnud ühetaoline ning see peegeldus ka eesti folkloristika arengus. Sõjajärgsed aastad oli suhteliselt leebe hingetõmbeaeg, kultuuriuuringutes nimetatud ka ,järel-eesti ajaks" (nt Kreegipuu 2007), mil folkloristidki üritasid sõjaeelseid töid jätkata, kohandades oma kirjutisi vaid pisut valitsevate poliitiliste oludega sobivaks. Stalinistliku laine põhjas (Olesk 2003), aastail 1947-1953, levis repressioonide ja (enese)kriitika lainetus - nii horisontaalselt impeeriumi keskmest üle Nõukogude Liidu vabariikide kui ka vertikaalselt-hierarhiliselt parteijuhtidest kuni Eesti loomeliitude liikmete ja reateadlasteni (vt Zubkova 2007; Kreegipuu 2007).

Eesti (ja Balti ehk „uute” nõukogude vabariikide) folkloristid sisenesid sovetlikku paradigmasse Moskvas, Kiievis jm impeeriumi keskustes toimunud üleliidulistel konverentsidel, kus põhikõnelejateks olid vene, aga ka teiste „kogenud” vennasvabariikide folkloristid. Seal toimus uude süsteemi haaratud teadlaste ,järeleaitamine" nõukogude folkloristlike meetodite osas ning anti juhiseid uurimis- ja kogumistöö korraldamiseks. Neilt konverentsidelt saadud suuniseid arutati põhjalikult Eesti asutuste koosolekutel (nn tootmisnõupidamistel) ning neist anti ülevaateid ajakirjanduses (vt Ahven 2007: 65, 80-81). Meetodi omandamine seisnes suuresti „revolutsiooniklassikute” tsitaatide ning sovetliku diskursuse vormelite oskuslikus kasutamises, mida demonstreerivad ilmekalt tollased avalikkusele suunatud kirjutised (nt Laugaste $1950 \mathrm{~b})$.

Esmapilgul näib, et pidevalt rõhutatud rahvalikkuse ja rahvaloomingu olulisus ning eeskujulikkus lubanuks ju rahvaluule kogumisel ja uurimisel tõusta muutunud ühiskondlikes oludes humanitaaria hierarhia tippu. Nagu kirjutatakse 1944. aastal ilmunud anonüümses referaadis „Stalini mõtteid rahvaloomingust":

Omistades rahvaloomingule suure tähtsuse, pidas Lenin seda rahva hingeelu tundmaõppimise allikaks. V. Bontš-Brujevitši mälestuste järgi soodustas ning ergutas Lenin igati rahvaluule materjalide kogumist, lugedes seda tähtsaks ja vajalikuks tööks. Ka Lenini järglane seltsimees Stalin kutsub üles õppima rahva praktilistest kogemustest. Tema vaated rahvaloomingule on tihedas seoses tema suhtumisega töötavale rahvale. 
Ja tõesti, sõjajärgsele aastakümnele oli iseloomulik, et nii loomeinimeste kui ka folkloristide tähelepanu oli pööratud nn rahvaloomingule - kaasaegsele folklooriharrastusele. Uudsete kultuuriinstitutsioonide ${ }^{1}$ kaudu korraldati „rahvakunstiõhtuid” prestiižsetes esinemispaikades (Estonia teatri lava!), taidlejate ülevaatusi ja kursusi, professionaalse kultuuri loojaid suunati võtma eeskuju rahvakultuurist. Kuid küsimus on selles, mida rahvakultuurina mõisteti. Kas sellel oli ühisosa rahvaluulega? Ja kuidas suhestus rahvaluule ja/või rahvakultuuri kogumine, uurimine ja propageerimine stalinismi lõpuaastatel Eestit vallanud „kodanliku natsionalismi” väljajuurimise kampaaniaga (vt Zubkova 2009: $217 \mathrm{jj})$ ?

Siinse artikli mahus ei ole võimalik - ega otstarbekas - arutleda rahva ja rahvuse mõistete sisu üle erinevatel ajajärkudel ega süveneda marksistlikesse või Lenini ja Stalini „rahvusküsimuste” üksikasjadesse. Mitmete stalinismiaegse Eesti poliitilist või kultuurielu käsitlenud uurimuste põhjal saab järeldada, et Nõukogude Liidu põlisrahvusi toetav poliitika (vn коренизачия) vaheldus rahvusi sügavalt umbusaldava poliitikaga, vahelduste põhjused ei ole alati dokumenteeritud ning erinevaid lähenemisi kasutati vastavalt olukordadele (nt Feest 2007: 207-208). Süüdistusel kodanlikus natsionalismis polnud rahvuse ega etnilisusega olulist seost, see oli „nõukoguliku” vastandmõiste (vt Zubkova 2009: 217 jj). Natsionalistliku süüteo sisu võis olla juhuslik ja kodanliku natsionalismi mõiste toob irooniliselt meelde teisigi äärmiselt hägusa tähendusega või väärtusskaalal ootamatult muutunud mõisteid ja mõistepaare, nagu antipatriotism, internatsionalism-kosmopolitism, rahvuslik sotsialism. Kõigi nende ebamääraste ja ebajärjekindlalt tõlgendatud mõistete kasutamise eesmärk oli kultuurielu sovetiseerimine, ühiskondlike struktuuride nõukogude mudeli järgi unifitseerimine ning täitmine keskvõimule sobilike tegelastega (Kreegipuu 2007; Zubkova 2009). Seda eesmärki saigi kõige efektiivsemalt täita, tekitades ebakindluse ja hirmu õhkkonna, millele aitas kaasa süüdistustes kasutatud mõistete piiritlematus ning ootamatus (vt ka nt Kuuli 2005: 259-263; Zubkova 2007: 196-199; Feest 2007: 216-217).

Eesti folkloriste päästis natsionalismi lõksust kindlasti sõnade rahvus ja rahvas keeleline ning mõisteline lähedus (vt nt Ojamaa, Labi 2007). On selge, et rahvas, kelle rahvaluule mõiste ja käsitlus kujunes XIX sajandil, oli midagi muud kui rahvas, kelle rahvaloomingut XX sajandi keskel nõukogude folkloristid jäädvustasid ja edendasid. Eesti folkloristikas käibinud rahvaluule mõiste oli minevikku suunatud, see oli eelmodernse põllumajandusliku ühiskonna kultuuriliselt ja majanduslikult marginaliseeritud talupoegade suuline eneseväljendus. Ka XX sajandi eesti talurahvalt koguti eelkõige mälestusi vanemast traditsioonist ja arhailisest folkloorist. Nõukogude folkloristika tähelepanu kese seevastu oli kaasaeg, selle uurimisobjekt kuulus modernistlikku kultuurimudelisse, mil kultuuriline eneseväljendus oli juba argielust eraldunud ja kanaliseerus kas professionaalsesse või harrastuskultuuri.

${ }^{1}$ Rahvamajade muutmisest klubideks, Rahvaloomingu Keskmaja tekkest ning kultuuriharrastuse tsentraliseerimisest vt nt Kulbok-Lattik 2014. 


\section{Uus ja vana rahvaluule}

Üleliidulistelt konverentsidelt tõid eesti folkloristid kaasa uue uurimis- ja kogumissuuna - kaasaegne nõukogude folkloor, mille hulka loeti klassivõitluslik töölisfolkloor, Suure Isamaasõjaga seotud pärimus ning kolhoosifolkloor. Üheselt oli ette kirjutatud uue folkloori tundetoon ja suunitlus: „töötavad rahvahulgad" pidid kiitma Nõukogude juhte ja sõjaväge, uut kolhoosikorda, muutunud elukorraldust ning vastupidi, raevukalt ja satiiriliselt võitlema kodanliku Eesti ja Saksa okupatsiooni tegelaste, kolhoosikorra vaenlaste, "tagurlaste" vastu. ${ }^{2}$

Nõukogude folkloori tähelepanu keskmesse tõstmine ja klassikaliste folkloorižanride marginaliseerimine tõi aastail 1950-1952 katkestuse Eesti rahvaluulekogumises - tollest ajast on arhiivis üsna vähe üleskirjutusi. Eesti folkloristid üritasid folkloori mõiste muutunud sisuga kohaneda. Richard Viidalepp, juba sõjaeelses rahvaluulearhiivis töötanud folklorist ja kogenud rahvaluulekoguja, käis äsjaloodud Keele ja Kirjanduse Instituudi rahvaluule sektori töötajana Tartu ümbruse eesrindlikes kolhoosides, jäädvustades ja juhendades seinalehtedega tegelemist ning isetegevust. Ta püüdis talletada Suure Isamaasõja pärimust ning nõukogude tähtpäevade tähistamist, harida rahvalaulikuid ja amatöörluuletajaid kultuur-poliitiliselt jmt. Edukate ametlike raportite kõrval kajastavad välitööpäevikud ebaõnnestunud tegelikkust: nurjunud katseid leida sõdurilaulikuid, kolhoosiametnike huvipuudust, kokkulepete eiramisi, jõuetut asendustegevust. ${ }^{3}$ Sama tagajärjetud olid kirjandusmuuseumi folkloristi Hilda Nõu töölisfolkloori kogumise katsed IdaVirumaa kaevanduspiirkonnas ning mujal vanades töölisasulates. ${ }^{4}$

Uuelaadse materjali kogumisel olid edukamad üliõpilased. 1950. ja 1951. aastal saadeti Tartu Riikliku Ülikooli eesti kirjanduse ja rahvaluule kateedri tudengid Eduard Laugaste juhendamisel eriülesandega Kesk-Eesti kolhoosidesse kolhoosifolkloori talletama. Tudengid küsitlesid põhiliselt kolhooside ametnikke, lisaks majandusandmetele jäädvustasid nad teateid kultuuriliste harrastuste, kalendaarse ja perekondliku tavandi muutumise kohta jmt. Siiski, tugeva regilaulutraditsiooniga aladel toimunud kogumispraktikatel (näiteks Tõstamaal, Kihnus, Mustjalas) oli põhitähelepanu pööratud vanade pulmalaulikute otsimisele ja küsitlemisele - hoolimata avalikkusele esitatud uuenduslikust kuvandist (Niit 1950). ${ }^{5}$

1940. aastate lõpul toimunud suured ühisekspeditsioonid (vt edaspidi) viidi läbi n-ö klassikalistes rahvaluulepiirkondades Setumaal ja Kihnu saarel. Ena-

${ }^{2}$ Nõukogude folkloori kohta vt nt Kogumistöö juhendaja; Eesti kirjanduse ajalugu 1953: 8-9, 18-24, 55-62.

${ }^{3}$ Vt lähemalt Viidalepa päevikuid „Uurimismatk Elva ja Mustvee rajooni 30. sept. kuni 7. okt. 1950” (KKI 16, 405/96); „Matk Vastseliina rajooni kolhoosidesse augustis 1951” (KKI 17, 267/314); „Vastseliina kolhoosides sept/okt 1951” (KKI 17, 315/362). Siin ja edaspidi viidatud välitööpäevikud on kättesaadavad Eesti Kirjandusmuuseumi failirepositooriumi KIVIKE kaudu (http://kivike.kirmus.ee).

${ }^{4}$ Välitööpäevikud Jõhvist 1949. ja 1951. aastast (RKM II 32, 9/13; 181/204), Räpinast 1952. aastast (RKM II 28, 419/36) ning Pärnust ja Torist 1951. aastast (285/304).

${ }^{5}$ Võrdle nt Loreida Raudsepa „Päevik rahvaluule kogumisest Märjamaal 10.-20. VII 1950. a.” (EKRK I 1, 403/33) ja Heldur Niidu „Päevik rahvaluule kogumise matkalt Tõstamaale. 10. 07.-20. 07. 50. a.” (EKRK I 1, 103/130). 
mik seal talletatud materjalist kajastas vana traditsiooni. Nõukogude folkloori jäädvustati vähe, kuid avalikkusele esitati seda kogumistöö ülevaadete lõpus huvitava ja tähtsa lisandina (nt Viidalepp 1949). Huvi nõukogude folkloori vastu vaibus tasapisi juba enne Stalini surma. 1952. aastal alanud kirjandusmuuseumi ekspeditsioonidel Herbert Tampere juhtimisel keskenduti taas regilaulude päästekogumisele ning hiiumuistenditele, ka TRÜ tudengid suunati Virumaale kaardistama Kalevipoja kohti ja pärimust. Töölisfolkloori mainiti vaid vahel kogumispäevikutes, komandeeringupabereid külanõukogudes ja kolhoosikeskustes tembeldades visati pilk peale ka seinalehtedele.

Nõukogude folkloori kogumise aktsioon ebaõnnestus, sest spetsiifilist folkloori leiti vähe või kirjutati ekslikult üles „vale” materjali (Ahven 2007: 98-99; Kulasalu 2017: 142-144). Selle põhjused olid ilmselged: uut nõukogude folkloori Eestis veel ei olnud ega saanudki olla. Kolhoosid olid asutatud alles aasta-paar enne kogumisaktsiooni, uus kombestik ei olnud veel kujunenud. Ka tööliskonna struktuur oli muutunud: põlised töölissuguvõsad olid lõhutud, sissetoodud töölistel ei olnud seda pärimust, mida folkloristid ootasid. ${ }^{6}$ Suure Isamaasõja folkloori allikaks olnud sõdurite laulukladed sisaldasid lubatust tunduvalt lahknevat - ka saksa päritolu laule, kriitilisi laule jmt. Siin ilmnebki toonaste ettekirjutuste ja tegelikkuse vastuolu: ametlikult aktsepteeritavat folkloori ei olnud (veel) olemas, tegelikult eksisteerinud folkloor oli valitseva korra ja muutuste osas nii kriitiline, et seda ei juletud folkloristidele rääkida ega üles kirjutada. Nõukogude folkloori aktsiooni nurjumist Eestis näitab ka see, et sellest ei avaldatud ühtegi temaatilist tekstikogumikku ega uurimust. Kirjandusmuuseumi tööplaanis oli mitmete valimike koostamine, nt „Suure Isamaasõja aegsed eesti rahvalaulud”, „Valimik tööstustööliste ja kolhooside rahvaluulet” ning „Lenin ja Stalin eesti rahvaluules”, ${ }^{7}$ kuid valmis ei saanud neist ükski. Ühe vähese käsitlusena võib nimetada Viidalepa kirjutatud peatükki „Rahvaluule arengust nõukogude ajal” 1959. aastal ilmunud „Eesti rahvaluule ülevaates”. ${ }^{8}$ Isegi tudengite välitöödel kogutu põhjal ei kirjutatud ühtegi diplomitööd, kuigi toona oli see tavaks. ${ }^{9}$

Pärast Stalini surma 1953. aastal naasid folkloristid taas klassikaliste žanride juurde. Algas monumentaalsete rahvaluuleväljaannete ettevalmistamise ning folklooriekspeditsioonide buum (nt Saarlo 2012: 837-838, 2017b: 36-37). Folkloristid oppisid oma kirjutistes vastanduma „kodanlik-natsionalistlikele" uurimissuundadele (Eesti kirjanduse ajalugu 1953: 8), rõhutades folklooris väljendunud klassivõitlust ja rahvaste sõprust, mida eelmised režiimid ja folkloristid olevat natsionalistlikel põhjustel ignoreerinud. Kuigi Nõukogude Liidus jätkus kaasaegse folkloori kogumise suund (Annist 1962), jõudsid Eesti folkloristid kaasaegse temaatika juurde tagasi alles 1970. aastatel soome folkloristide eeskujul lastefolkloori kaudu (Kõiva 1995: 331-332).

${ }^{6}$ Tõtt-öelda folkloristid sissesõitnud töölisi või kolhoosnikke ei küsitlenudki, mis seostub traditsioonilise kuvandiga folkloorist kui kohasidusast traditsioonist.

${ }^{7}$ Käsikirjaline väljaannete prospekt leidub arhiivis ERA, EFAM.

${ }^{8}$ Samasuguseid ühiskondlikke ja teaduspoliitilisi murranguid läbinud läti folkloristidel on uuel ajal ilmunud mõned temaatilised kogumikud, vt Pakalns 1999; Kencis 2017.

${ }^{9}$ Erinevalt näiteks etnograafidest, kes samal ajal „kolhoosietnograafiat” jäädvustasid (Konksi 2004) ja jõudsid tulemusi ka lõputöödena vormistada (vt lõputööde nimekirja https://www.flku.ut.ee/et/kaitstud-tood (vaadatud 31. X 2017)). 


\section{Rahvaluule ja rahvalooming}

Kõige suurem takistus kaasaegse „nõukogude folkloori” paradigma omaksvõtul oli siiski vastuolu, mida eesti folkloristid nägid vanas „rahvaluule” ja nõukogulikus „rahvaloomingu” mõiste sisus. Nõukogude folkloristikas oli fookus kaasaegsele nõukogude folkloorile pööratud juba 1920. aastate lõpust ja sellel olid selged ideoloogilised põhjused: eemaldumine arhailistest, „kasututest” traditsioonidest, nõukogude kodaniku moderniseerimine (Panchenko 2005: 18-20). Eesti folkloristid sisenesid 1940. aastate lõpul üleliidulistel konverentsidel teravale võitlustandrile - just siis käis vene folkloristide omavaheline arveteklaarimine ja (enese)kriitikalaine (vt nt Kencis 2017: 156-157).

Ülevaated, mida eesti folkloristid üleliidulistelt foorumitelt kaasa toodud uute teadmiste levitamiseks asutustesisestel aruteludel esitasid, refereerisid vene folkloristide debatte folkloori olemuse üle ning arutlusi folkloori mõiste hülgamisest ja rahvaloomingu mõistega asendamisest. ${ }^{10}$ Folkloori definitsiooni kui suuliselt levivast rahva sõnalisest loomingust peeti vananenuks. Nõukogude „rahvalooming” oli modernse mõtlemise vili, sisaldades lisaks folkloorile ja folklooriharrastusele (folklorismile) ka kirjalikku väljendust ning individuaalset loomingut - põhimõtteliselt võiks seda interpreteerida rahvaluule kui kollektiivse ja anonüümse mitteinstitutsionaalse vaimse loomingu ja professionaalse institutsionaalse kultuuri vahepealse nähtusena. Eesti folkloristid võtsid avalikkusele suunatud kirjutistes küll uued suunised entusiastlikult vastu ning rahvaloomingu mõiste kasutusele (vt nt Päss 1950), kuid kinnisemas ringis esitatud ülevaadetes kõlasid umbusklikud toonid ning kurdeti selgete juhtnööride puudumise üle.

Kaasaegse folkloori ja rahvaloomingu kogumise ja uurimise peamine eesmärk uutes liiduvabariikides oli kahtlemata elanike sovetiseerimise fikseerimine ning kultuuriharrastuse praktikate kanaliseerimine sovetlikus traditsioonis aktsepteeritud suunda (vrd Kapper 2011). Kultuuriharrastuse kontrollimiseks loodi 1944. aastal Nõukogude Liidu eeskujul Tallinnasse Rahvaloomingu Keskmaja, kust koordineeriti nii eestlastele harjumuspärast kultuurilist isetegevust (koorilaul, etlemine, harrastusteatrid) kui ka folklooriharrastust.

Rajoonilised ülevaatused on juba toimunud peaaegu kõikjal. Nende tulemused kõnelevad kollektiivseisse majapidamistesse liitunud talurahva suurtest edusammudest sisult sotsialistliku ja vormilt rahvusliku kultuuri rikastamisel. Seejuures on märkimisväärne mitte üksnes kunstilise isetegevuse avardumine laiades rahvahulkades, vaid ka ideelis-kunstilise taseme tõus, mis avaldub nii repertuaari sisukuses kui ka ettekandelise taseme tõusus. (Kolhoositalurahvas valmistumas 1951)

Üldsuse ees realiseerus see kontroll rahvalaulikute-muusikute ning taidlejate püünele toomises. Üle Eesti korraldati konkursse, mille parimad said esineda „rahvaloomingu õhtutel”, nagu eespool öeldud, väga prestiižsetel lava-

${ }^{10} \mathrm{Nt}$ Elmar Pässi ülevaade Moskva üleliidulisest folkloristide konverentsist 20.-30. oktoobrini 1949; Richard Viidalepa ülevaade Nõukogude Baltikumi folkloristide konverentsilt Riias 24.-29. märtsini 1951 (ettekannete käsikirjad asuvad arhiivis ERA, EFAM). 
del. Sellega tõsteti taidluse väärtus professionaalse kultuuriga näiliselt samale tasandile.

Harrastuskultuuri konkurssidel olid žüriis ka folkloristid, neilt eeldati panust taidlejate juhendamisel. Kõige enneolematumad nähtused olid siiski koolitusüritused, mis olid suunatud rahvalaulikute kultuurilis-poliitilisele „järeleaitamisele”. Nii näiteks oli 1951. aasta detsembris toimunud „rahvalaulikute, rahvapillimeeste ja omaloominguliste autorite kokkutulek-seminari” kavas lisaks ülevaatele rahvaloomingust loengud rahvusvahelisest olukorrast, Stalini kujust nõukogude muusikas ning konsultatsioonid laulusõnade ning muusika osas. Eraldi töö toimus setu rahvalaulikutega (mh hääleseade (!)) ning rahvapilliorkestritega. Ettekandeid pidasid folkloristidest Selma Lätt, Herbert Tampere ja Richard Viidalepp, aga ka kirjanikud ning heliloojadmuusikud (Debora Vaarandi, Edgar Arro, Valter Ojakäär jt). ${ }^{11}$

Rahvaloomingu mõiste rõhutas laiade töötavate rahvahulkade loomingulisust, selle loomingu väärtust ning elavat folklooriprotsessi, marginaliseeris aga traditsiooni tähendust. Kuigi eesti folkloristikas kasutati rahvaloomingu mõistet rahvaluule sünonüümina, hägustas taidluse (mis ei sisaldanud üksnes folklooriharrastust) mõistealasse kaasamine folkloori tähendust.

Kaasaegse folkloori ja folklooriprotsessi jäädvustamine ning uurimine oli sõjaeelses Eestis olnud tärkav ja uudishimu tekitav uurimisala. ${ }^{12} \mathrm{Ka}$ folklooriharrastuse - folklorismi - osa eesti rahvusliku eneseteadvuse hoidmisel on raske ülehinnata, selles on suur osa folkloristide rahvaluulet populariseerivatel kirjutistel ning tekstikogumikel. Kuid stalinismiaegne sundkorras kultuuriharrastusega tegelemine - mh šefluse nime all - põhjustas vastumeelsuse nii kaasaegse rahvaluule kui ka folklorismi vastu, eesti folkloristide enamik hoidis edaspidi oma uurimisala kiivalt autentse rahvaluule juures. Folklorismi ja folklooriliikumise analüüsimisega ei ole seetõttu Eestis enne XXI sajandit kuigi palju tegeletud - peale Ingrid Rüütli silmapaistva erandi. ${ }^{13}$

\section{Rahva looming ja kunstilooming}

Kõigist kunstivormidest tähtsaimaks peeti Nõukogude Liidus kirjandust, millest annab tunnistust muuhulgas Stalini sõnavõttude arv kirjanduse teemadel (Kreegipuu 2007: 354-355). Kuna rahvaluulet peeti kirjanduse eelastmeks, langes ka rahvalauludele suurte juhtide tähelepanelik silm. Jätkates valgustus-romantilist ettekujutust „rahva geeniusest”, tehti omal nõudlikul moel professionaalsetele kunstnikele, heliloojatele ja kirjanikele ülesandeks võtta eeskuju just rahvaloomingust.

Rahvas on kõikvõimas. Ta on ajaloo võimas edasiviija, kultuuri looja. Surematu on rahvalooming, mis sisaldab endas ammendamatu allika kunstile. Pidevalt soovitades nõukogude kirjanikele, kunstnikele, poeetidele, heliloojaile, kino- ja teatritöölistele pöörduda rahva geeniuse ammendamatu varaaida poole, hoo-

${ }^{11}$ Seminari programm asub arhiivis ERA, EFAM.

12 Walter Andersoni ja Viidalepa tuntud panusele (nt Anderson 1926; Viidalepp 1937) lisanduvad paljud tudengite kogud Eiseni ja Andersoni juhendamisel.

${ }^{13}$ Nt Rüütel 1970, 1977. Ingrid Rüütli bibliograafiat vt Rüütel 2010. 
litseb seltsimees Stalin väsimatult rahvuslike kunstide arendamise eest. [---] Sotsialistlik kunst peab olema loodud rahvale ja peab tuginema rahva enda loomingule - see mõte käib punase niidina läbi kõigist sm. Stalini väljendusist. (Stalini mõtteid rahvaloomingust 1944)

Seetõttu ongi tähelepanuväärne, et stalinistliku laine harjal halvustati n-ö puhast, autentset rahvakultuuri, seda peeti tagurlikuks, „museaalseks”. Nii tõstab K. Arba 1949. aastal Estonia teatri laval toimunud „rahvakunsti ôhtust" kirjutades positiivselt esile rahvatantsumotiividel uudisloomingut ning paneb pahaks autentseid rahvamuusika esitusi.

Asjaolu, et meie rahvatantsuharrastajad on hakanud oma repertuaari täiendama uusloominguga, näitab, et on üle saadud varaseimast natsionalistlikest ja muuseumlikult alalhoidlikest, arengut pidurdavaist eelarvamustest, nagu peaks rahvatantsu harrastus piirduma vaid minevikupärandina muuseumidesse talletatud vormide mehaanilise kordamisega. [---]

Samuti ei saa nõustuda sellega, kui õhtute kavasse, kus rahvakunst esineb tänapäevaselt viimistletud ja organiseeritud kujul, põimitakse sisse puhtetnograafilis-teadusliku väärtusega ettekandeid, nagu käesoleval juhul Setu ansambli ja 70-aastase rahvalauliku Anna Lindvere omad. Nende esinemine, mis asjatundjaile on salgamatult väga huvitav ja väärtuslik, mõjus üldkava raames üsnagi dissoneerivalt. (Arba 1949)

Kas just teadlikult, aga üsna selgelt ja ajastuomaselt on arvustaja teinud vahet rahvuslikul ja rahvalikul, rahvaluulel ja rahvalikul loomingul. Rahvaluule kuulub minevikku ja selle koht on muuseumis, tänapäeval on rahvaluule vajalik üksnes harrastuskultuuri ja kunstiloomingu allikmaterjalina.

See on üsna huvitav ja ohtlik vastuolu, kuhu sõjajärgse Eesti folkloristid sattusid, kui nad ühelt poolt pidid lähtuma loosungist „rahvakultuur on Nõukogude kultuuri alus" (Eesti kirjanduse ajalugu 1957: 126) ja teisalt olid sunnitud kõlavalt tõestama, et „kodanliku diktatuuri” aegne kultuurielu oli elitaristlik ja „eemaldunud rahvast”. See väide oli ju otsene vale, millele osutavad mitmed uurimused sõjaeelse Eesti kultuurielu kohta. Nii näiteks eesti rahvusliku muusikakeele kujundamise vaidlustes polnud küsimus mitte selles, kas rahvamuusikale toetuda, vaid kuidas seda teha (vt nt Lippus 2008: 195-196).

Igatahes, stalinismi ajal kasutusel olnud loosung „sotsialistlik sisu rahvuslikus vormis” tähendas muuhulgas seda, et suur osa sõjajärgsest professionaalsest heliloomingust tehti rahvamuusika ainetel. Positiivset suhtumist on näha hinnangutest, mida Harri Kõrvits andis noorte Tartu heliloojate rahvusliku helikeelega teostele:

Esitatud tööd (kahe klaverisonaadi üksikosad) vihjavad J. Räätsi muusika sisukusele ja rahvuslikule helikeelele. [---] Oma loomingu rahvalikkuselt paistsid silma ka Tartu muusikakooli IV kursuse õpilased Allikvee ja Jürisson. [---] Tunnustust väärib Jürissoni püüe rikastada meie heliloomingut rahvapilliorkestri repertuaariga. Esitatud „Hällilaulus” ja „Lõikuspeos” on märgata tihedat sidet eesti rahvamuusikaga, mille intonatsioonide loomingulise ümbertöötamisega autor kirjeldab elu kolhoosikülas. (Kõrvits 1951) 
Märkimisväärselt ajastuomane on seejuures kolhoosielu kujutamine rahvamuusika töötlusi kasutades, ehk tõepoolest sotsrealism rahvuslikus vormis. Peatumata Eesti muusikalool pikemalt, peab siiski tõdema, et rahvamuusika ja rahvaliku vormi kasutamine heliloomingus ei päästnud mitmeid heliloojaid repressioonidest, ning rõhutatud rahvalikkus vaesestas uudisteoste helikeelt (Lippus 2008: 195). Rahvamuusika kasutamine ongi jäänud Eesti professionaalse muusikakultuuri ja rahvusliku helikeele iseloomulikuks osaks.

Folkloristide ülesanne rahvaloomingu ja kunstiloomingu ühendamisprotsessi käigus oli tarnida professionaalsetele kunstnikele inspiratsiooni- ja allikmaterjali. See tähendas, et folkloristidelt eeldati rahvaluule kogumist ja kättesaadavaks tegemist (arhiivides korraldamist ja avaldamist). Huvi ja vajadus allikate järele tõi (taas kord) kaasa rahvaluule kogumistöö hoogustumise.

\section{Kollektiivne kogumine}

Välitööde korraldus oli üks töömeetodeid, mis sõjajärgsel aastakümnel Eesti folkloristikas muutus. Rahvaluulekogumise algusest peale XIX sajandil olid välitööd Eestis toimunud üksi või kahekesi retkel käies, keskendudes tihtipeale ühele kindlale teemale. Üleliidulistelt konverentsidelt tõid folkloristid kaasa aga uue kollektiivse töövormi - frontaalse ekspeditsiooni -, mis tähendas suure osavõtjate hulgaga, mitme eriala ja/või institutsiooni esindajatega peamiselt mõnes maapiirkonnas toimunud välitöid. Frontaalse ekspeditsiooni eesmärk oli teatud maa-alalt kogu vaimse teabe, nii poeetilise kui ka näiteks ajaloolise pärimuse, murdekeele jms jäädvustamine. Ekspeditsioonide töökorraldus (salvestustehnika, liikumisvahendid, olme) institutsionaliseeris ja intensiivistas folkloori jäädvustamist ning formaliseeris folkloristide ja informantide suhteid (Oras 2008: 60 jj). Avalikkusele suunatud kirjutistes kasutatud retoorika ja stampväljendid olid aga siingi vastuolus tegeliku olukorraga - folkloristid alles õppisid kollektiivselt töötama.

Ekspeditsiooni tööle on viljastavalt mõjunud ekspeditsiooniliikmete tootmisnõupidamised koha peal. (Laugaste 1947)

Olin endale pahane, et ma siiski ei kasutanud sel hommikul aktiivsemat veenmismeetodit. Meil oleks siiski olnud vaja see retk teha ära koos kogu kollektiiviga. Nüüd kujunes asi teisiti ja see mõnevõrra kahjustas meie tööd. (Viidalepp $1955(\mathrm{KKI} 20,391 / 2))$

Eesti folkloristikas ei jäänud püsima interdistsiplinaarsed ekspeditsioonid, küll aga kaasati järjepidevalt välitöödele muusikuid või muusikatudengeid rahvamuusika süstemaatiliseks kogumiseks. Ka uue salvestustehnika kättesaadavus soodustas vanade esindusžanride - regilaulude, muistendite ja muinasjuttude - pääste- ja eeliskogumist (Saarlo 2017a: 127-130).

Teine kogumise intensiivistumise külg oli andekate laulikute ja jutustajate repertuaari korduv jäädvustamine. Lisaks variantide kuhjamisele aitas see kaasa uue uurimissuuna arengule: rahvaluule variatiivsuse ning rahva- 
lauliku isikupära uuringuile 1950 . aastate teisel poolel. ${ }^{14}$ Frontaalsed kogumisekspeditsioonid olid üks väheseid omaksvõetud nõukogude uuendusi, mis sobis eesti folkloristide missiooniga päästa kadumisest vanu folkloorižanre, talletades neid tihedalt kindlast piirkonnast. Need ekspeditsioonid toimusid nii rahvaluuletudengitel kogumispraktika raames kui ka professionaalsetel folkloristidel järjepidevalt 1990. aastate lõpuni.

\section{Eesti ja vene rahva sõprus}

Eesti rahva ühinemine Nõukogude Liiduga on avanud meile tee laiaulatuslikuks läbikäimiseks teiste vennasrahvastega ja loonud suuri võimalusi nendega kultuuriliste väärtuste vahetamiseks, esmajoones meie eesrindlikuma naabri, vene rahvaga. See pole mingi juhuslik või uus nähtus, vaid juba pika ajaloolise traditsiooni loomulik jätkamine, mis ainult lühikeseks ajaks oli kodanluse võimutsemise päevil vägivaldselt katkestatud. (Tampere 1949)

Stalinismiaegsetes kirjutistes väideti, et kodanlikus teaduses varjati ja alavääristati eesti ja vene rahva sõbralikke suhteid (Eesti kirjanduse ajalugu 1953: 8). Tõepoolest, kogu eesti folkloristika ajaloos on keskendutud justnimelt eesti rahvaluule kogumisele ja uurimisele, Jakob Hurda üldrahvalik kogumisaktsioon oli „suur isamaaline töö”, mis sai üheks ehituskiviks rahvusliku identiteedi kujundamises ja ühise rahvuse konstrueerimise protsessis. Sõjaeelses Eesti Vabariigis polnud naaber- ja vähemusrahvaste folkloor just peavoolu kogumis- ja uurimisteema, kuid siiski ka mitte päris marginaalne. Tänu nii Paul Ariste kui ka Oskar Looritsa isiklikele uurijahuvidele on vene rahvusvähemuse pärimust sisaldav ERA Vene-nimelise käsikirjaseeria suurus märkimisväärsed 17 köidet ehk ligi 10000 lk (vt Viidalepp 1986: 164; Salve 2002: 34-38).

Otse loomulikult olid Eesti haritlased kohustatud sõjajärgsetel aastatel sisenema venekeelsesse teadusruumi. Eesti kultuuri ja teaduse vene keeleruumi eksportimine algas juba enne sõda, kohe pärast Eesti okupeerimist 1940. aastal (vt Ahven 2007: 30). Eesti-vene suhete teema uurimise vajadus tõstatati peatselt pärast sõja lõppu. Rahvusteaduste uurijad kohandusid kohustusliku temaatikaga ja asusid uurima eestlaste etnogeneesi, milleks koguti ja analüüsiti arheoloogia, etnograafia ja dialektoloogia segarahvastikuga aladel toimunud välitööde andmeid (nt Moora, A. 1956; Moora, H. 1964). Eesti ajalugu kirjeldati muistse Vene riigi ajaloo raames (nt Eesti NSV ajalugu 1957: 19-20, 30-32). Sealjuures rõhutati idaslaavi ja vene mõjusid, läänemeresoomelised sidemed või skandinaavia, germaani ja balti suhted jäeti tagaplaanile või üldse mainimata.

Eduard Laugaste, kes täitis sõjajärgses eesti folkloristikas mitmeid juhtivaid rolle ja avaldas seetõttu mitmeid programmilisi artikleid rahvaluuleteaduse ees seisvatest uuenduslikest ülesannetest, oli oma seisukohtades suhteliselt tasakaalukas (vt nt Laugaste 1945, 1947, 1950b). Mõneti üllatavalt ei olnud vene rahvaluule tema kirjutistes üldse esil.

${ }^{14}$ Näiteks Ottilie Niinemägi (Kõiva) uurimused Kihnu laulikutest ning Udo Kolgi uurimused regilaulu vormelitest ja variaablusest (Kõiva 1964; Kolk 2013). 
Eesti-vene suhete alase materjali kogumise vajadusest on vaid lühikesed laused ettekannete tekstides, mis esitati uurimismaterjali kogumist ning korraldamist käsitlevatel konverentsidel ja diskussioonikoosolekutel 1948. aasta veebruaris Riiklikus Kirjandusmuuseumis. ${ }^{15}$ Sama aasta aprillis toimunud Teaduste Akadeemia Ühiskonnateaduste Osakonna teadusliku sessiooni ettekannete katusteemaks oli „Eesti-Vene suhted ajalooliselt”, kus Viidalepp ja Tampere esinesid ettekannetega eesti-vene suhetest erinevates folklooriliikides. ${ }^{16}$

Veel samal aastal saadeti mõned vene filoloogia tudengid Petserimaale ja Peipsi rannikule vene folkloori koguma, ${ }^{17}$ ka professionaalsete folkloristide ekspeditsioonid korraldati järgnevatel aastatel segarahvastikuga piirialadele Peipsi ümbruses: Alutagusele, Kodaverre ja Setumaale. Tavapärase eesti folkloori kogumise kõrval külastasid vene keelt oskavad folkloristid vene külasid ja talletasid sealset folkloori.

Siiski jäid need korjandused suhteliselt kõrvaliseks - käsikirju arhiveeriti eesti materjalist eraldi, nende põhjal ei valminud eriuurimusi. Kui TRÜ vene keele kateeder hakkas ise välitöid tegema, ${ }^{18}$ vaibusid ka eesti folkloristide katsetused vene pärimuse jäädvustamiseks. Eelarvamuslikust suhtumisest vene folkloori kogumisse annab tunnistust kas või see, et sõjajärgse perioodi käsikirjaline seeria RKM, Vene sisaldab vaid neli köidet. Kuigi eesti folkloristidel võiski olla huvi vene folkloori ja eesti pärimuse suhete vastu, siis ametlik ülepaisutatud russofiilia (vt Annus 2017: $6 \mathrm{jj}$ ) vaigistas selle edukalt. Asendusena pöörati tähelepanu hõimurahvaste folkloori kogumisele, mida tehti sageli etnograafide tuules (Salve 2002: $45 \mathrm{jj}$ ).

\section{Kalevipoeg ja nõukogude rahvalaulikud eesti folkloristika päästjana}

Eesti folkloristid leidsid pääsetee ebasobivatest teemadest kõrvalehoidmiseks, pöördudes teise nõukogude humanitaarteadustes soositud ja nõukogude retoorikaga ülimalt haakuva teema juurde - eeposed ja kangelaseepika.

Eesti rahvuseepose „Kalevipoeg” retseptsioon oli ilmumisest saati vastuoluline, kirjanduslik ja folkloristlik huvi teose vastu oli 1930. aastatel vaibunud (vt Annist 2005: 43-46). Samas oli Kalevipoja tähtsus sõjaeelses rahvuslik-poliitilises diskursuses vaieldamatu. Mõneti iroonilisel kombel võeti riigikorra muutudes üle just see ametlik patriootlik ja heroiline hoiak.

Kohe Nõukogude okupatsiooni alguses 1940. aastal alustati „Kalevipoja” uustõlgete ja tutvustamistega Nõukogude Venemaal. Sõja järel jätkus „Kalevipoja" triumf seoses mitmete kultuurilooliste tähtpäevadega (lisaks Kreutzwaldi 150. sünniaastapäevale möödus neil aastail sajand „Kalevala” ja „Kalevipoja”

${ }^{15}$ Konverentsi „Teadusliku uurimismaterjali kogumistöö probleeme ENSV TA Ühiskonnateaduste Osakonna asutistes" ettekanded ning otsused asuvad Eesti Kirjandusmuuseumi arhiivis (f 24, n 1, s 112).

${ }^{16}$ Konverentsist ja ettekannetest lähemalt vt Roose 1948; vt ka Tampere 1949; Viidalepp 1951.

${ }^{17}$ Käsikirjaseeria RKM, Vene kolmes esimeses köites on 1640 lehekülge üliõpilaste üleskirjutusi aastaist 1948-1949.

${ }_{18}$ Tartu Riikliku Ülikooli vene keele kateedri ja vene kirjanduse kateedri rahvaluulekogu TRÜ, VKK algatati 1961. aastal. 
eri versioonide ilmumisest) ning eeposte tähtsusega nõukogude folkloristikas. Aastatel, mil Jakob Hurt ja Matthias Johann Eisen kuulutati tagurlasteks (Eesti kirjanduse ajalugu 1953: 8), nimetati Faehlmanni ja Kreutzwaldi demokraatlikeks kirjanikeks ning Kalevipoega „töötava rahva vägilaseks, eesti töömehe võrdkujuks”, tema kunagisi „dekadentlikke rahvavaenulikke” kriitikuid Noor-Eesti rühmitusest aga formalistideks (Laugaste 1950a).

Võib öelda, et 1950. aastatel oli „Kalevipoja” uurimine moevool, mis päästis eesti folkloristid kolhoosifolkloorist ja taidlusest. Ajajärku iseloomustas vulgaarsotsioloogiline lihtsustamine, faktide eiramine või mittetundmine, mistõttu eepost tõlgendati väga ühesuunaliselt, kunstilise väärtuse uurimine jäi täiesti kõrvale (Annist 2005: 47-51). Siiski, „Kalevipoja” uustõlgete ja redaktsioonide valmimine andis võimaluse eepose uurimise tõusuks, mis „oleks võimatu samal ajal mitte uurides eesti rahvaluulet, rahvamuistendeid ja regivärssi" (Laugaste 1957: 4).

Seetõttu algas kohe 1950. aastal kolhoosifolkloori kogumisega paralleelselt Kalevipoja paikadega seotud pärimuse kogumine, mida esmalt tegid TRÜ tudengid dotsent Eduard Laugaste juhtimisel Virumaal, ${ }^{19}$ hiljem ka professionaalsed folkloristid kogu Eesti ulatuses. Hiiumuistenditega seotult muutus kohasidusa pärimuse talletamine folkloristlike välitööde kanooniliseks osaks.

Eeposte tähtsuse üks põhjuseid oli nende rahvalikkus - just eeposes nähti „rahvaliku geeniuse” ülimat ilmingut, eepilist rahvaluulet esitavad laulikud võeti kirjanike liitude liikmeteks ja nende loomingu talletamisele pöörati erilist tähelepanu (vt nt Nõukogude Liidu rahvalaulikud; Andresen 1949). Nõukogude rahvalaulikute eeskujul oodati ka Eesti laulikutelt kompositsioone nõukogude juhtide ja kolhoosikorra kiituseks - ja saadigi. See andis ettekäände külastada korduvalt tuntud laulupiirkondi - Setumaad ja Kihnu saart, kuhu toimusid ekspeditsioonid 1940. aastate lõpus ja 1950. aastatel järjepidevalt (vt nt Kulasalu 2017; Oras 2008: 63-64).

\section{Kokkuvõtteks}

Eesti folkloristika tegi sõjajärgsel aastakümnel sovetiseerimise käigus läbi samasuguseid muutusi nagu ülejäänud Eesti humanitaaria. Eesti folkloristidele oli tähtis ,jõuda järele” marksistlike meetodite ja sovetliku diskursuse osas „kogenud” nõukogude folkloristidele ning siseneda uude, „nõukogude rahvaloomingu" paradigmasse. Nad olid sunnitud laveerima rahvaliku ja rahvusliku vahel ning loobuma arhailise folkloori kogumisest ja uurimisest.

Siiski ebaõnnestus sisenemine uude uurimisparadigmasse. Eesti folkloristid suutsid kohaneda muutustega nii, et sisuliselt midagi uut folkloristikasse toomata, üksnes diskursust vahetades jäeti mulje uue „marksistliku meetodi” omandamisest, uusi kogumisülesandeid täideti üsna pinnapealselt.

Eestist oli äärmiselt vähe võimalik leida uutele ootustele vastavat folkloori, kuna poliitilised ja majanduslikud muutused olid toimunud alles hiljuti. Seda enam, et tegelikult levinud rahvaluulet ei saanud repressioonide hirmus

${ }^{19}$ Eduard Laugaste oli juhtival positsioonil nii eepose uusredaktsioonide kui ka hiljem hiiumuistendite köidete avaldamise juures. 
talletada. Väheseid sobivaid leide tutvustati innukalt ettekannetes üleliidulistel foorumitel ning avalikkusele suunatud kirjutistes. Kaasaegse pärimuse ja kultuuriharrastuse ühendamine rahvaloomingu mõistes oli eesti folkloristidele arusaamatu ja sobimatu, mistõttu jäi vastuvõetamatuks ka folklooriharrastus võimaliku uurimisobjektina. Kuigi folkloristid on alati huvitunud erinevate kultuuride kokkupuudetest ja segunemisest, said uute võimude pealesunnitud silmakirjalikud Vene-uuringud nii vastumeelseks, et neist loobuti esimesel võimalusel. Uute ülesannete ebaõnnestumise kõige ilmselgem tunnistus on uurimuste ja ülevaadete puudumine.

Nii saabki öelda, et sovetiseerimine konserveeris eesti folkloristika. Vastureaktsioonina nõukogude folkloristika teatavale modernsusele keskendusid eesti folkloristid taas klassikaliste folkloorižanride ning rahvusliku folkloori kogumisele ja uurimisele. Nõukogude folkloristikas prominentse kangelaseepose uurimisteema toel pöörduti „Kalevipoja” kaudu uuesti regilaulude ja muistendite päästekogumise ning väljaandmise juurde. Folkloorižanride hierarhia säilis: esiplaanil olid arhailised žanrid, nagu regilaul, muistend, muinasjutt; pisutki uuemad žanrid ja liigid, nagu lõppriimiline rahvalaul, pajatus, lastepärimus, jäid marginaaliasse. Kaasaegse(ma) folkloori kogumise ja uurimise lainest jäädi seetõttu aga kõrvale kuni 1980. aastateni.

Artikli valmimist toetasid Eesti Haridus- ja Teadusministeerium (IUT22-4 „Folkloor kultuurilise kommunikatsiooni protsessis: ideoloogiad ja kogukonnad”) ning Euroopa Liit Euroopa Regionaalarengu Fondi kaudu (Eesti-uuringute Tippkeskus).

\section{Käsikirjalised allikad}

EKRK - Tartu (Riikliku) Ülikooli eesti kirjanduse ja rahvaluule kateedri käsikirjaline rahvaluulekogu

ERA - Eesti Rahvaluule Arhiivi käsikirjaline rahvaluulekogu

ERA, EFAM - Eesti Folkloristika Ajaloo materjale

Eesti Kirjandusmuuseumi Arhiiv, f 24

KKI - Keele ja Kirjanduse Instituudi käsikirjaline rahvaluulekogu

RKM - Eesti TA Fr. R. Kreutzwaldi nim. (Riikliku) Kirjandusmuuseumi rahvaluule osakonna käsikirjaline rahvaluulekogu

TRÜ, VKK - Tartu Riikliku Ülikooli vene keele kateedri ja vene kirjanduse kateedri rahvaluulekogu

\section{Kirjandus}

A a r elaid, Aili 1998. Ikka kultuurile mõeldes. Tallinn: Virgela.

A hven, Eeva 2007. Pilk paberpeeglisse. Keele ja Kirjanduse Instituudi kroonika 1947-1993. Tallinn: Eesti Keele Sihtasutus.

Anders o n, Walter 1926. Die Marspanik in Estland 1921. - Zeitschrift des Vereins für Volkskunde, nr 35/36, lk 229-252. 
Andresen, Nigol 1949. „Kalevala” mälestuspäevade puhul. - Looming, nr 3, lk $352-358$.

Ann is t, August 1962. Rahvalooming ja kaasaeg. - Looming, nr 12, lk 1897-1909.

Annist, August 2005. Friedrich Reinhold Kreutzwaldi „Kalevipoeg”. Tallinn: Eesti Keele Sihtasutus.

Annus, Epp 2017. Ma tõstan klaasi vene rahva terviseks: sotskolonialismi diskursiivsed alustalad. - Methis. Studia humaniora Estonica, nr 20. Sotskolonialismi erinumber. Koost, toim E. Annus, lk 4-26.

Arba, K. 1949. Mõtteid rahvakunstiõhtult. - Sirp ja Vasar 8. I, nr 2.

Eesti kirjanduse ajalugu: õpik keskkooli VIII klassile. 1. Toim Endel Sõgel. Eesti NSV Teaduste Akadeemia Keele ja Kirjanduse Instituut. Tallinn: Eesti Riiklik Kirjastus, 1953.

Eesti kirjanduse ajalugu. 1. Toim Endel Sõgel. Eesti NSV Teaduste Akadeemia Keele ja Kirjanduse Instituut. Tallinn: Eesti Riiklik Kirjastus, 1957.

Eesti NSV ajalugu. Kõige vanemast ajast tänapäevani. Toim Gustav Naan. Tallinn: Eesti Riiklik Kirjastus, 1957. Teine trükk.

Feest, David 2007. Põlisrahvuste taaseelistamise poliitika Balti liiduvabariikides? Eestimaa Kommunistlik Partei pärast Teist maailmasõda. - Eesti NSV aastatel 1940-1953. Sovetiseerimise mehhanismid ja tagajärjed Nõukogude Liidu ja Ida-Euroopa arengute kontekstis. Koost Tõnu Tannberg. (Eesti Ajalooarhiivi toimetised. Acta et Commentationes Archivi Historici Estoniae 15 (22).) Tartu: Eesti Ajalooarhiivi Kirjastus, lk 207-224.

Gor ši č, Ave 2017. Kirjandusmuuseumi ja humanitaarteaduste ümber toimunud avalik diskussioon aastatel 1967-1968. - Keel ja Kirjandus, nr 10, lk 771-786.

Ka p per, Sille 2011. Pärimus ja jäljendus. Postkolonialistlik katse mõista rahvatantsu olukorda Eesti NSV-s ja pärast seda. - Methis. Studia humaniora Estonica, nr 7. Nõukogude aja erinumber. Koost Sirje Olesk, Tiina Saluvere, lk 222-236.

Kencis, Toms 2017. The Soviet project of new folklore. - Mapping the History of Folklore Studies: Centers, Borderlands and Shared Spaces. Toim Dace Bula, Sandis Laime. Newcastle upon Tyne: Cambridge Scholars Publishing, lk 154-169.

Kogumistöö juhendaja 1948 = Kogumistöö juhendaja rahvaluule alal. 1. Eesti NSV Teaduste Akadeemia Riiklik Kirjandusmuuseum. Tartu: Teaduslik Kirjandus.

Kolhoositalurahvas valmistumas $1951=$ Kolhoositalurahvas valmistumas II vabariiklikule kunstilise isetegevuse ülevaatusele. - Sirp ja Vasar 10. III, nr 10.

Kolk, Udo 2013. Folkloori olemust otsides. Koost, toim Madis Arukask. (Ilmatargad.) Tartu: Ilmamaa.

Konksi, Karin 2004. Arved Luts ja Nõukogude Eesti kaasaja dokumenteerimine Eesti Rahva Muuseumis. - Eesti Rahva Muuseumi aastaraamat XLVIII, lk 13-46.

Kre egi pu u, Tiiu 2007. Eesti kultuurielu sovetiseerimine. Nõukogude kultuuripoliitika eesmärgid ja institutsionaalne raamistik aastatel 1944-1954. - Eesti NSV aastatel 1940-1953. Sovetiseerimise mehhanismid ja tagajärjed Nõukogude Liidu ja Ida-Euroopa arengute kontekstis. Koost Tõnu Tannberg. (Eesti Ajalooarhiivi toimetised. Acta et Commentationes Archivi Historici Estoniae 15 (22).) Tartu: Eesti Ajalooarhiivi Kirjastus, lk 352-388. 
Kulasalu, Kaisa 2017. From Estonian Folklore Archives to Folklore Department of the State Literary Museum: sovietization of folkloristics in late Stalinist Estonia. - Mapping the History of Folklore Studies: Centers, Borderlands and Shared Spaces. Toim Dace Bula, Sandis Laime. Newcastle upon Tyne: Cambridge Scholars Publishing, lk 132-153.

Kulbok-Lattik, Egge 2014. The Sovietization of Estonian community houses (rahvamaja): Soviet guidelines. - Acta Historica Tallinnensia, nr 20, lk 157-190.

Kuuli, Olaf 2005. Muutuvad parteitekstid (1946-1952). - Kohanevad tekstid. Koost, toim Virve Sarapik, Maie Kalda. Tartu: Eesti Kirjandusmuuseum, Eesti kultuuriloo ja folkloristika keskus, Tartu Ülikooli eesti kirjanduse õppetool, lk 259-270.

Kõiv a, Mare 1995. Koolipärimuse kogumise ja kogumiku saateks. - Lipitud-lapitud. (Tänapäeva folkloorist 1.) Tartu: Eesti TA Eesti Kirjandusmuuseum, Eesti TA Eesti Keele Instituut, lk 331-334.

Kõiva, Ottilie 1964. Kihnu rahvalaulikutest. (Tartu Riikliku Ülikooli toimetised 159.) Tartu: Tartu Riiklik Ülikool.

Kõresaar, Ene 2005. Elu ideoloogiad. Kollektiivne mälu ja autobiograafiline minevikutõlgendus eestlaste elulugudes. (Eesti Rahvamuuseumi sari 6.) Tartu: Eesti Rahva Muuseum.

Kõ rvits, Harri 1951. Tartu heliloojate tööst. - Sirp ja Vasar 10. III, nr 10.

Laugaste, Eduard 1945. Mida tehakse ja kavatsetakse folkloori alal. - Rahva Hääl 26. X, nr 253.

La ug a s te, Eduard 1947. Kokkuvõtteid ja hinnanguid eesti rahvaluuleuurimise seniste saavutuste kohta. - Looming, nr 8, lk 995-1003.

La uga s te, Eduard 1950a. „Kalevipoja” tähtsus eesti kirjanduses. - Edasi 21. V, nr 119.

La ugaste, Eduard 1950b. Ülesandeid Nõukogude Eesti rahvaluuleteaduses. Edasi 4. XI, nr 262.

La ug a t e, Eduard 1957. Saateks. - „Kalevipoja” küsimusi. (Tartu Riikliku Ülikooli toimetised 53.) Tartu: Tartu Riiklik Ülikool, lk 3-5.

Li p p u s, Urve 2008. Eesti muusika kaotused Nõukogude okupatsiooni läbi. - Kannatuste aastad 1940-1991. Toim Ülo Ennuste, Enn Tarvel, Peep Varju. Tallinn: Valge Raamat, lk 175-214.

Mo or a, Aliise 1964. Peipsimaa etnilisest ajaloost. Ajaloolis-etnograafiline uurimus Eesti-Vene suhetest. Eesti NSV Teaduste Akadeemia Ajaloo Instituut. Tallinn: Eesti Riiklik Kirjastus.

Mo ora, Harri (toim) 1956. Eesti rahva etnilisest ajaloost. Eesti NSV Teaduste Akadeemia Ajaloo Instituut. Tallinn: Eesti Riiklik Kirjastus.

Niit, Heldur 1950. Kolhoosifolkloor nõuab endale täit eluõigust. - Sirp ja Vasar 23. IX, nr 38.

Nõukogude Liidu rahvalaulikud 1940. Esmaspäev: piltidega nädalleht, 21. IX, nr 38. URL: http://dea.digar.ee/cgi-bin/dea?a=d\&d=esmaspaev19400921.2.26 (17. III 2017).

Oj a m a a, Triinu, La bi, Kanni 2007. Natsioon, natsionalism ja muusika. - Akadeemia, nr 11, lk 2343-2369.

Olesk, Sirje 2003. „Laine põhi”. Kirjandusest ja selle kontekstist Eestis aastatel 1950-1953. - Võim ja kultuur. Toim Arvo Krikmann, S. Olesk. Tartu: Eesti Kirjandusmuuseum, lk 465-479. 
Or a s, Janika 2008. Viie 20. sajandi naise regilaulumaailm. Arhiivitekstid, kogemused ja mälestused. (Eesti Rahvaluule Arhiivi toimetused 27.) Tartu: Eesti Kirjandusmuuseumi Teaduskirjastus.

Or a s, Janika 2009. Lõik eesti folkloorikogumise loost. Nõukogude aja helisalvestused. - Akadeemia, nr 4, lk 703-724.

Pakalns, Guntis 1999. „Nõukogude inimene suudab kõike” - jutustamisteema sotsialismi ja postsotsialismi ajastul. - Kuuldust-nähtust. Toim Eda Kalmre. (Tänapäeva folkloorist 4.) Tartu: Eesti Kirjandusmuuseum, lk 45-60.

Panchenko, Alexander A. 2005. The cult of Lenin and 'Soviet Folklore'. - Folklorica. Journal of the Slavic and East European Folklore Association, nr 10 (1), lk 18-38.

Päs s, Elmar 1950. Üleliiduline folkloristide konverents Moskvas. - Sirp ja Vasar 9. XII, nr 49.

R o o s e, Felix 1948. Eesti ja vene rahva sõprussidemed (Eesti NSV Teaduste Akadeemia II teaduliku sessiooni ettekannete valgusel). - Looming, nr 6, lk 732-733.

Rü üt el, Ingrid 1970. Laulmisest tänapäeval. - Rahvapärimuste koguja 7. Tartu, lk 5-6.

Rü ütel, Ingrid 1977. Mõtteid folkloorist ja taidlusest. - Kultuur ja Elu, nr 7, lk $35-40$.

Rü ütel, Ingrid 2010. Muutudes endaks jääda. Valik meenutusi, artikleid, uurimusi. Tallinn: TEA Kirjastus.

S a a r lo, Liina 2012. Kaks hõbekeelset kannelt helisemas taas... - Keel ja Kirjandus, $\mathrm{nr}$ 11, lk 836-846.

S a a r lo, Liina 2017a. Regilaul in the political whirlpool: On collecting Regilaul in Northeast Estonia in the second half of the 1950s. - Folklore. Electronic Journal of Folklore, nr 67, lk 115-142.

S a a r lo, Liina 2017b. Regilaul tuulte pöörises. Eesti folkloristid poliitiliste muutuste ajajärgul 20. sajandi keskel. - Methis. Studia humaniora Estonica, nr 20. Sotskolonialismi erinumber, lk 27-54.

Salve, Kristi 2002. Muude rahvaste folkloor Eesti Rahvaluule Arhiivis. - Kogumisest uurimiseni. Artikleid Eesti Rahvaluule Arhiivi 75. aastapäevaks. (ERA Toimetused 20.) Tartu, lk 29-52.

Stalini mõtteid rahvaloomingust 1944. - Sirp ja Vasar 23. XII, nr 11.

Z u bkova, Jelena 2007. Probleemne tsoon: Balti vabariikide sovetiseerimise iseärasused sõjajärgsel ajal 1944-1952. - Eesti NSV aastatel 1940-1953. Sovetiseerimise mehhanismid ja tagajärjed Nõukogude Liidu ja Ida-Euroopa arengute kontekstis. Koost Tõnu Tannberg. (Eesti Ajalooarhiivi toimetised. Acta et Commentationes Archivi Historici Estoniae 15 (22).) Tartu: Eesti Ajalooarhiivi Kirjastus, lk 184-206.

Z u b k ov a, Jelena 2009. Baltimaad ja Kreml. 1940-1953. Tallinn: Varrak.

T a m pere, Herbert 1949. Vene mõjusid eesti vanemais rahvaviisides. - Sirp ja Vasar 15. I, nr 3.

Tann berg, Tõnu (koost) 2007. Eesti NSV aastatel 1940-1953. Sovetiseerimise mehhanismid ja tagajärjed Nõukogude Liidu ja Ida-Euroopa arengute kontekstis. (Eesti Ajalooarhiivi toimetised 15 (22).) Tartu: Eesti Ajalooarhiivi Kirjastus.

Viidalepp, Richard 1937. Von einem grossen estnischen Erzähler und seinem Repertoir. - Acta Ethnologica, kd 2, nr 3, lk 158-173. 
Viidalepp, Richard 1949. Kolm ekspeditsiooni Eesti rahvaluule uurimiseks. Järvalane 9. VIII, nr 93.

Viid a le p p, Richard 1951. Kalevipoeg - eesti ja vene rahva iidse sõpruse kehastaja. - Nõukogude Õpetaja 31. VIII, nr 35.

Viidalepp, Richard 1959. Rahvaluule arengust nõukogude ajal. - Eesti rahvaluule ülevaade. Toim R. Viidalepp. Eesti NSV TA Keele ja Kirjanduse Instituut. Tallinn: Eesti Riiklik Kirjastus, lk 471-483.

Vi i d a l e p p, Richard 1986. Meie esimene ekspeditsioon. - Keelest ja rahvaluulest. Emakeele Seltsi aastaraamat 30. 1984. Tallinn, lk 163-172.

\section{Sovietisation as a preservative for Estonian national folkloristics}

Keywords: Sovietisation, Stalinism, research policy, national sciences, folkloristics, fieldwork

In the first post-war decade, Estonian folklore studies were, like the rest of the Estonian humanities, subjected to certain impacts of Sovietisation, which brought along not only institutional reforms but also changes in the research paradigm. As a result, the folklorists had to perform some tricky maneuvers with the words rahvalik 'popular' and rahvuslik 'national; ethnic', and to withdraw, for a period, from collecting and studying archaic folklore, which used to be the core of Estonian national folkloristics.

Estonian folklorists adapted to the changes so that without bringing practically anything new to the field, just by changing the discourse, they managed to leave an impression of having acquired a new "Marxist method", while the novel tasks of fieldwork addressing contemporary Soviet folklore and the tradition reflecting Russian-Estonian ethnic relations were taken rather lightly.

Actually, Estonian folklore of the time was extremely poor in the material anticipated, because the political and economic changes had taken place only recently. The few findings matching the new paradigm, however, were publicised with great zeal. As the possibility of connecting both folklore and hobby culture under popular creative activities seemed strange to Estonian folklorists, hobby folklore was never included among research objects. The unsolicited and hypocritical Russian studies were abandoned first chance. Total absence of relevant publications can be seen as evidence of the failure of the new tasks.

Hence the conclusion that Sovietisation acted as a preservative for Estonian folkloristics. Although Estonian folklorists had already studied contemporary folklore as well as the folklore of ethnic minorities in the pre-war period, as soon as Stalinism showed signs of moving to the close they immediately returned to the collection and studying of the old "classical" genres of national folklore. It was actually Kreutzwald's Kalevipoeg, fitting into the theme of heroic epics that happened to be prestigious in Soviet folkloristics, which provided the researchers an escape back to the rescue collecting and publication of runic songs and old legends.

So the archaic genres of folklore remained in the foreground of research up to the final decades of the 20th century, while more recent folklore failed to attract research attention until the 1980 s.

Liina Saarlo (b. 1974), PhD, Estonian Folklore Archives, Estonian Literary Museum, researcher, liina.saarlo@folklore.ee 